\title{
細管内気液二相流のボイド率特性*
}

\author{
植田忠伸*1, 竹中信 幸*2, 浅野等*3 \\ 杉本勝 美*3, 川端祐 司*4, C. M. SIM*5
}

\section{Void Fraction Characteristics of Gas-Liquid Two-Phase Flow in a Small Diameter Tube}

\author{
Tadanobu UEDA*6, Nobuyuki TAKENAKA, Hitoshi ASANO, \\ Katsumi SUGIMOTO, Yuji KAWABATA and C. M. SIM \\ ${ }^{* 6}$ Department of Mechanical and Systems Engineering, Kobe University, \\ 1-1 Rokkodai-cho, Nada-ku, Kobe-shi, Hyogo, 657-8501 Japan
}

\begin{abstract}
Void fraction of nitrogen gas-water two-phase flow in a circular tube from 1 to $10 \mathrm{~mm}$ in diameter was measured by neutron radiography. The measured void fraction results were compared with Ishii's drift flux model based on Mishima-Ishii's flow regime criteria. The void fraction was predicted well in annular flow region except for $\alpha<0.8$. Mishima-Ishii flow regime map was modified by a churn to annular flow transition criterion of $\alpha=0.8$. The void fraction was predicted well by Ishii's drift flux model in annular flow region in every diameter tubes.
\end{abstract}

Key Words: Multi-Phase Flow, Heat Exchanger, Void Fraction, Drift Flux Model, Small Diameter Tube, Flow Regime

\section{1. 緒言}

熱交換器などの流路には，伝熱面積の向上，小型化など の目的で，内径の細 流路を用いることが多い．この細管 内での気液二相流の流動は，従来用いられてきた径の太い 管とは異なり, 内径が小さくなると表面張力の影響が顕著 となる. また，管径が $5 \mathrm{~mm}$ 以下になると静止水中の単一気 泡の上昇速度が零になることが知られている(1).

Bamea ら ${ }^{(2)}$ は，内径が $4 \sim 12.3 \mathrm{~mm}$ の水平・垂直のガラス 管について実験を行い，流動様式線図を得ている. Mishima と Hibiki ${ }^{(3)}$ は，管内径が 1４mm のアルミニウム製円管につ いて管内佳の影響を調べ，全体積流束が $20 \mathrm{~m} / \mathrm{s}$ 以下の条件 で細管におけるドリフトフラックスモデル相関式を得てい る. 細管内の気液二相挙動に関する研究は，流動様式，圧 力損失などの基礎デー夕について行われてきたが，ボイド 率予測についての知見は少ない(3)(5).

* 原稿受付 2007 年 7 月 20 日.

*1 正員, 神戸大学大学院自然科学研究科(画 657-8501 神戸市 灘区六甲台町 1-1).

*2 正員, フェロー, 神戸大学大学院工学研究科.

*3 正員, 神戸大学大学院工学研究科.

*4 京都大学原子炉実験所( (590-0494 大阪府泉南郡熊取町朝 代西 2).

*5 Korea Atomic Energy Research Institute (P. O. Box 105, Yuseong, Daejeon, 305-600 Korea).

E-mail : tadanobu_ueda@stu.kobe-u.ac.jp
新型軽水炉の燃料集合体として検討されている䄷密ロッ ドバンドルは，サブチャンネルの水力等価直径力数 $\mathrm{mm}$ 程 度と小さく, 従来のバンドルの安全設計に使用されてきた ボイド率予測式が適用できるか検討する必要がある.

本研究では，中性子ラジオグラフィを用いて，内径 1〜 $10 \mathrm{~mm}$ の円管内垂直上昇窒素ガス一水気液二相流の断面平 均ボイド率を計測し, Mishima-Ishii の流動様式線四から推定 される環状流領域のボイド率が Ishii のドリフトフラックス モデルではよく予測できない領域が存在するという結果が 得られ，予測法を検討したので報告する.

\section{2. 記号}

$$
\begin{array}{ll}
A & : \text { 管断面積 }\left[\mathrm{m}^{2}\right] \\
C_{0} & : \text { 分布パラメータ } \\
D & : \text { 内径 } \\
V_{G j} & : \text { ドリフト速度 }[\mathrm{m} / \mathrm{s}] \\
j & : \text { 全体積流束 }[\mathrm{m} / \mathrm{s}] \\
g & : \text { 重力加速度 }\left[\mathrm{m} / \mathrm{s}^{2}\right] \\
u & : \text { 流速 }[\mathrm{m} / \mathrm{s}] \\
\alpha & : \text { 断面平均ボイド率 } \\
\delta & : 1 \text { 画素の幅 }[\mathrm{m}] \\
\mu & : \text { 粘性係数 }[\mathrm{Pa} \cdot \mathrm{s}] \\
\mu_{m} & : \text { 質量減衰係数 }\left[\mathrm{cm}^{2} / \mathrm{g}\right]
\end{array}
$$




$$
\begin{aligned}
\rho & : \text { 密度 }\left[\mathrm{kg} / \mathrm{m}^{3}\right] \\
\sigma & : \text { 水の表面張力 }[\mathrm{Pa}] \\
\text { 添 } & \\
G & : \text { 気相 } \\
L & : \text { : 液相 }
\end{aligned}
$$

\section{3. 実邪装置およひ方法}

$3 \cdot 1$ 実験装置 図 1 に本実験て使用した実験装置及 びその配置を示す。作動流体は, 常温, 大気圧の窒素と水 を用い，主にスラグ流，チャーン流，環状流領域で実験を 行った. 試験部は，1，2mm についてはステンレス製， 3 , 5，6，8，10 mmについてはアルミニウム製の郵直円管を用 いた。試験部は，助走区間 $100 \mathrm{Dmm}$, ボイド率測定部 $100 \mathrm{~mm}$, 測定部下流から出口までの距離を $200 \mathrm{~mm}$ とした. ギアポン プより水を供給し, 気液混合部内で $\mathrm{N}_{2}$ タンクより供給さ れた窒素と混合させた，気液混合部は，1，2mm 管につい ては T字管, $3 \mathrm{~mm}$ 以上の管については多孔質樹脂を用いた 混合部により, 窒素と水を混合させた. ボイド率の測定は, 中性子ラジオグラフィによって行った.

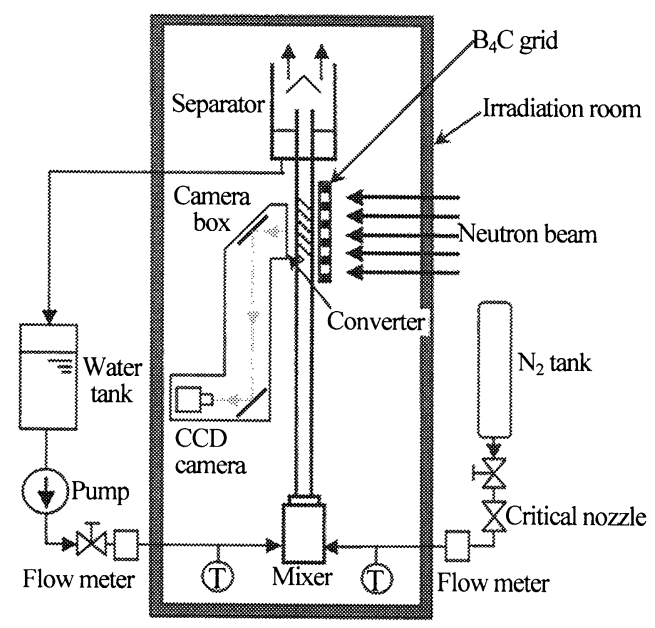

Fig. 1 Experimental apparatus

熱中性子ラジオグラフィ設備として, 京都大学原子炉実 験所(KURRI)B4 ポートおよび, 韓国原子力研究所(KAERI) NR ポートを用い実験を行った。試験部に中性子線を照射し, 二相流によって減衰した中性子線を蛍光コンバータで可視 光に変換し,カメラボックス内て鏡により光軸を曲げ, $\mathrm{CCD}$ カメラによって撮影した. カメラボックス内で光軸を曲げ る理由は，中性子ビームから跑離をとることでカメラ素子 の放射線による損傷を防ぎ， $\gamma$ 線ノイズを低减させるため
である. 撮影は KURRI では，画素数 $772 \times 580$ ，露光時間 10 秒，KAERI では，画素数 $1340 \times 1300$ ，露光時間 15 秒で 冷去型CCD カメラを用い撮影した. 圾験部を通過した気液 二相流は，試験部上部の分離部で気水分離され，窒素は大 気開放，水はポンプに戻し循環させた. ガス流量と液流量 は，体積流量計を用い測定を行った。. 各流体温度は，気液 混合部手前に設置した $\mathrm{K}$ 型シース熱電対により測定した. 実験は， $j_{G}=0.1 \sim 43 \mathrm{~m} / \mathrm{s}, j_{L}=0.03 \sim 2.2 \mathrm{~m} / \mathrm{s}$ の範井で行った.

\section{$3 \cdot 2$ 中性子ラジオグラフィとボイド率算出法}

中性子ラジオグラフィは, 中性子線の透過率の差異 を利用した可視化計測法であり，中性子線が大抵の金 属を透過し，水素や特定の元素で減衰する特性を有す る. 水で大きく減衰するため, 金属管内の二相流流動現象 の可視化計測に適しており, プレート熱交換器のや沸騰流 (7)(8)，エンジンのインジェクションノズル内キャビテーショ ンのの可視化計測などに用いられている.

断面平均ボイド率 $\alpha$ は, 撮影された二相流の画像 $S_{n}$, 水の存在しない画像 $S_{l}$ と各々のオフセット $O, O_{I}$ から 求められる(10).

$$
\alpha=1+\frac{\delta}{\mu_{m L} A} \sum_{n} \ln \left(\frac{S_{n}(x, y)-O(x, y)}{S_{1}(x, y)-O_{1}(x, y)}\right)
$$

ここで, $\delta$ は 1 画素の幅, $\mu_{m L}$ は水の質量减衰係数, $A$ は管断面積である. 中性子ラジオグラフィによってボ イド率を定量的に計測するために, $\mathrm{B}_{4} \mathrm{C}$ 製の中性子吸 収体グリッドを用いた真影法(10)により，オフセットを 計測した. オフセットは, 物体での中性子の散乱や力 メラボックス内での光の散乱, カメラの暗電流などに よるものである. 著者らは内径 $10 \mathrm{~mm}$ のボイド率測定 に対する不確かさ解析を行っており ${ }^{(11)}$, 今回のボイド 率計測の条件では, チャーン流, 環状流では数\%以下, スラグ流では $20 \%$ 程度の不確かさが予想される。

\section{4. 実検秸果および考察}

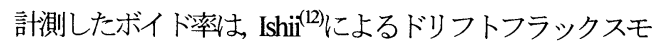

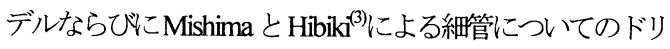
フトフラックスモデルと比較した. 流動様式の判別は Mishima と Ishii による流動様式線図 ${ }^{(1)}$ を用いた。

Mishima と Ishii による流動梯式半师拭は, 気泡流からスラグ流に対して,

$$
\alpha=0.3
$$


スラグ流からチャーン流に対し，

$\alpha=1-0.813\left[\frac{\left(C_{0}-1\right) j+0.35 \sqrt{\Delta \rho g D / \rho_{L}}}{j+0.75\left(\Delta \rho g D / \rho_{L}\right)^{1 / 2}\left[\Delta \rho g D^{3} /\left(\rho_{L} v_{L}^{2}\right)\right]^{1 / 8}}\right]^{0.75}$

チャーン流から環状流に対しては，

$$
D<\frac{\sqrt{\sigma / \Delta \rho g}\left\{\mu_{L} /\left[\rho_{L} \sigma \sqrt{\sigma /(g \Delta \rho)}\right]^{j / 2}\right\}^{-0.4}}{\left(1 / C_{0}-0.11\right)^{2}} \cong 50 \mathrm{~mm}
$$

であるので，小口径管用の判妿式

$$
j_{G}=\sqrt{\frac{\Delta \rho g D}{\rho_{G}}}(\alpha-0.11)
$$

を用いた。

ドリフトフラックスモデルより, 体積流束と平均ドリフ ト速度との関係は次式で表され，分布パラメータとドリフ 卜速度の值は，流動様式に応じて変化する(12).

$$
u_{G}=\frac{j_{G}}{\alpha}=C_{0} j+V_{G j}
$$

\section{Ishii による円管の相関式はそれぞれ次式で与えられる。}

気泡流：

$$
C_{0}=1.2-0.2 \sqrt{\frac{\rho_{G}}{\rho_{L}}}, \quad V_{G j}=(1-\alpha)^{1.5} \sqrt{2}\left\{\frac{\sigma g\left(\rho_{L}-\rho_{G}\right)}{\rho_{L}^{2}}\right\}^{1 / 4}
$$

スラグ流 :

$$
\begin{aligned}
& C_{0}=1.2, \quad V_{G j}=0.35\left\{\frac{g D\left(\rho_{L}-\rho_{G}\right)}{\rho_{L}}\right\}^{1 / 2} \\
& \text { チャーン流: } \\
& C_{0}=1.2-0.2 \sqrt{\frac{\rho_{G}}{\rho_{L}}}, \quad V_{G j}=\sqrt{2}\left\{\frac{\sigma g\left(\rho_{L}-\rho_{G}\right)}{\rho_{L}^{2}}\right\}^{1 / 4}
\end{aligned}
$$

環状流：

$$
C_{0}=1.0, \quad V_{G j}=23\left\{\frac{\mu_{L} j_{L}}{\rho_{G} D}\right\}^{1 / 2} \frac{\rho_{L}-\rho_{G}}{\rho_{L}}
$$

Mishima と Hibiki ${ }^{(3)}$ は，細管での静止水中の気泡の上昇速 度が零になることから, ドリフト速度を零とおき, 次式を 得ている.

$$
u_{G}=\frac{j_{G}}{\alpha}=C_{0} j, \quad C_{0}=1.2+0.510 e^{-0.691 D}
$$

ここで，管内径 $D$ の単位は $\mathrm{mm}$ である.

図 2 に計測したボイド率 $\alpha_{\text {exp }}$ と Mishima と Hibiki の 細管のドリフトフラックスモデル, Ishii のドリフトフ ラックスモデルによる予測値 $\alpha_{c a l}$ との比較を示す.

Mishima と Hibiki によるモデルのボイド率予測を中実 記号, Ishii によるモデルの予測を中空記号で示す．ス ラグ流, ‘チャーン流領域ではどちらのモデルも実験值 の不確かさによる誤差の範囲にある. 管径が $3 \mathrm{~mm}$ 以 上では，予測值と実験值は $20 \%$ 範囲内で一致してい るが，環状流においては，管径 1，2mm と同様に特異 な傾向を示す．Mishima と HIbiki のモデルでは環状流 の高ボイド域で実験值がモデルよりも高くなり一致し ないが, Mishima と Hibiki はモデルの有効な範囲を全 体積流束 $20 \mathrm{~m} / \mathrm{s}$ までと定義しているので妥当な結果だ といえ, 予測值はどの管径においてもボイド率が約 0.8 を境に実験值から外れる傾向を示す。一方, Ishii のモ デルでは，環状流領域でどの管径においても高ボイド 率でよく一致し, 低ボイド率では, 実験值よりもモデ ルのほうが低くなっている.この傾向は管径が小さく なるにつれ，より顕著に現れ，いずれの管径でも環状 流領域の $\alpha<0.8$ の条件では, Ishii のモデルは, 実験値 と一致しない.

Jones と Zuber ${ }^{(14)}$ は，水力等価直径が約 $9 \mathrm{~mm}$ の矩形管につ いて気液二相流実験を行い，スラグ流力ら環状流への遷移 がボイド率約 0.8 で起こることを報告している. Barnea ら (2) は, Mishima と Ishii の流動様式線図のチャーン流の 領域よりもガス流速の高、領域でチャーン流を観察し ている.

実験結果より，チャーン流から環状流への遷移が $\alpha=0.8$ で起こると仮定し, Ishii の環状流のドリフトフ ラックスモデル, 式(6), (10)に $\alpha=0.8$ を代入して, 流動 様式の境界線を加えた。修正した流動様式線図を図 3 に示す. $\alpha=0.8$ により設定した領域は, 管径の減少と 


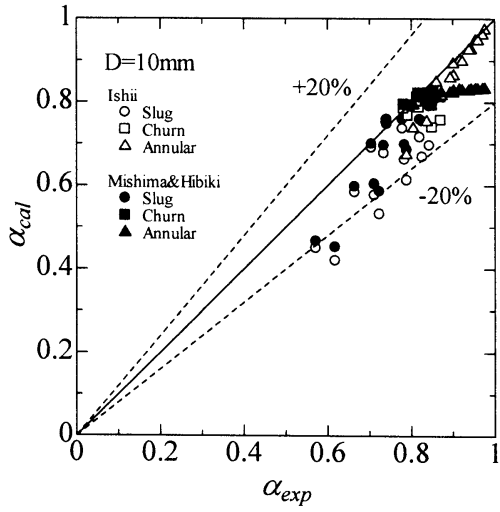

(a) $10 \mathrm{~mm}$

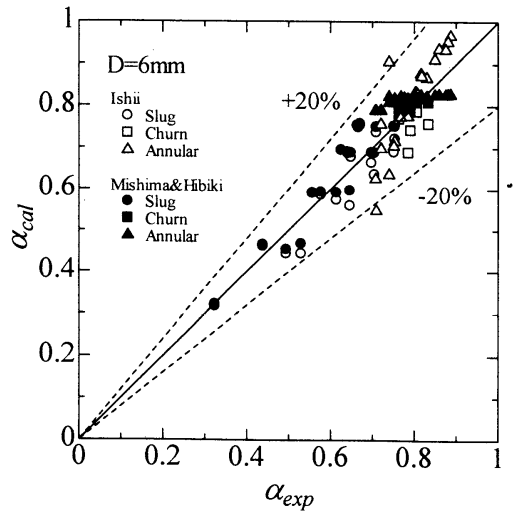

(c) $6 \mathrm{~mm}$

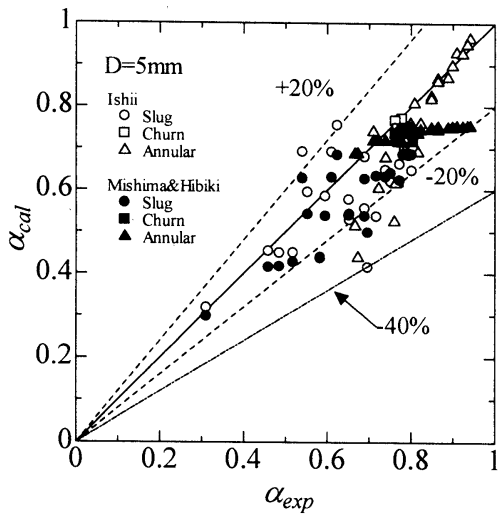

(d) $5 \mathrm{~mm}$

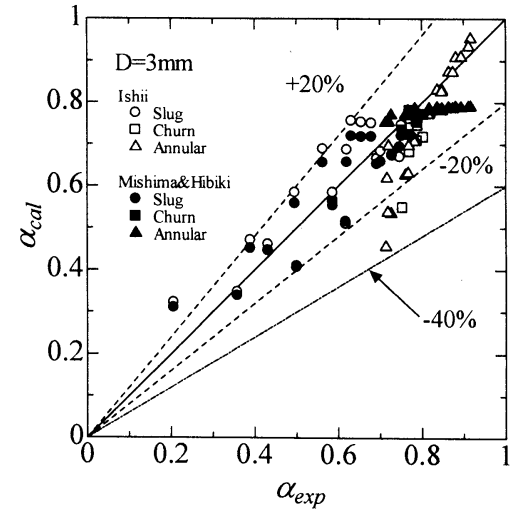

(e) $3 \mathrm{~mm}$

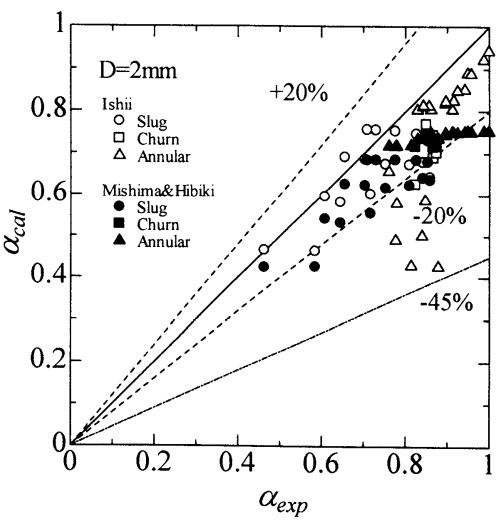

(f) $2 \mathrm{~mm}$

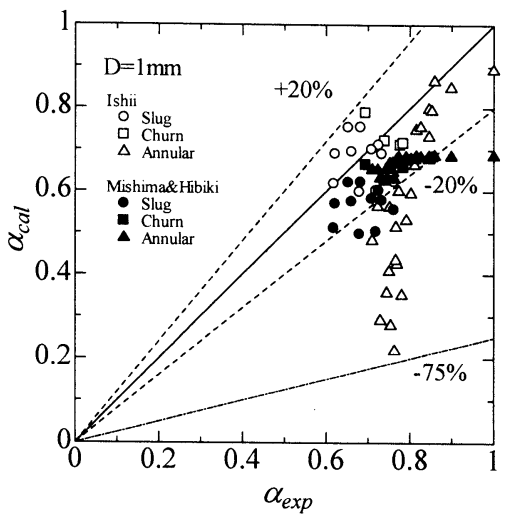

(g) $1 \mathrm{~mm}$

Fig.2 Prediction of the void fraction by Ishii and Mishima-Hibiki drift flux model 


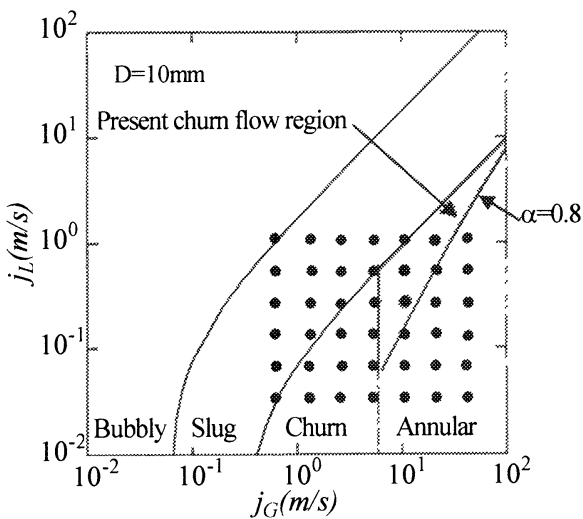

(a) $10 \mathrm{~mm}$

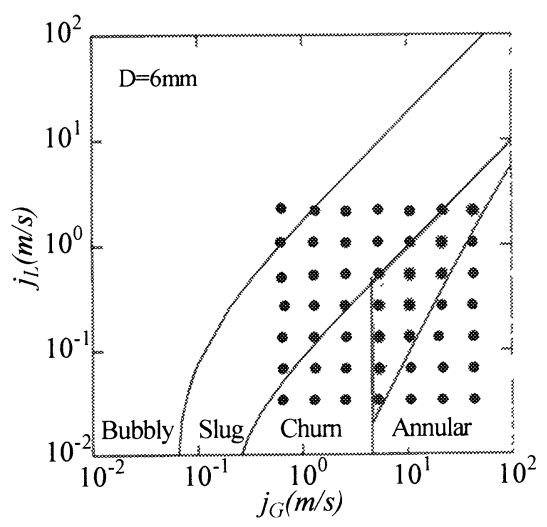

(c) $6 \mathrm{~mm}$

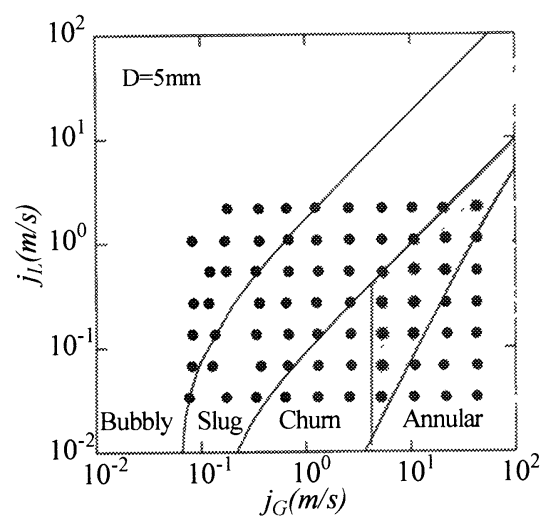

(d) $5 \mathrm{~mm}$

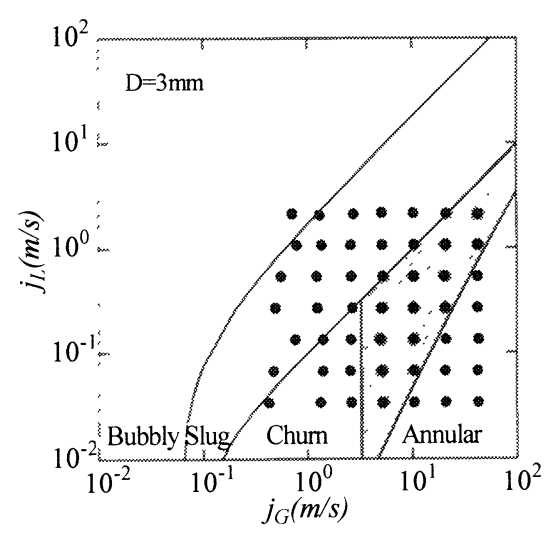

(e) $3 \mathrm{~mm}$

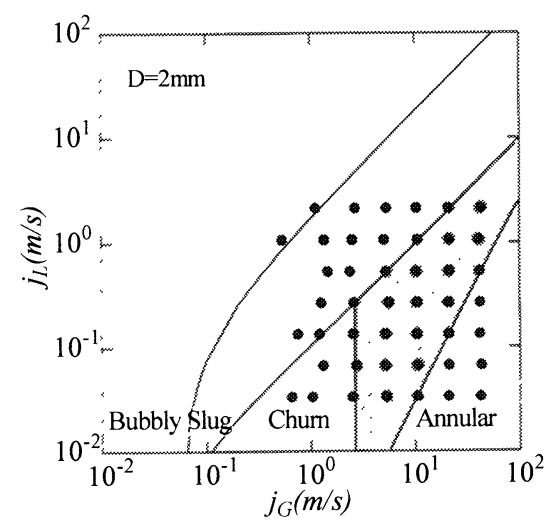

(f) $2 \mathrm{~mm}$

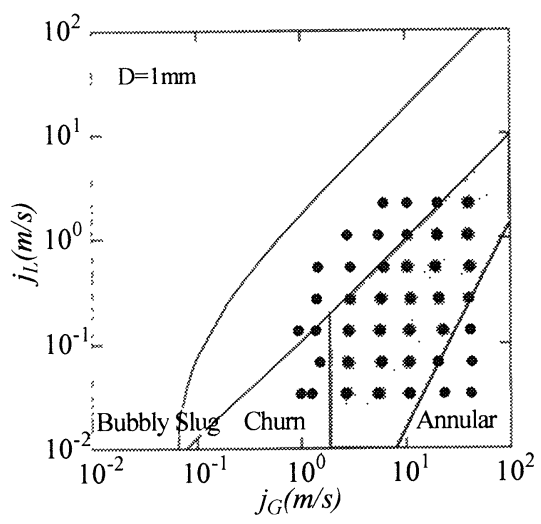

(g) $1 \mathrm{~mm}$

Fig.3 Modified Mishima-Ishii's flow regime map 


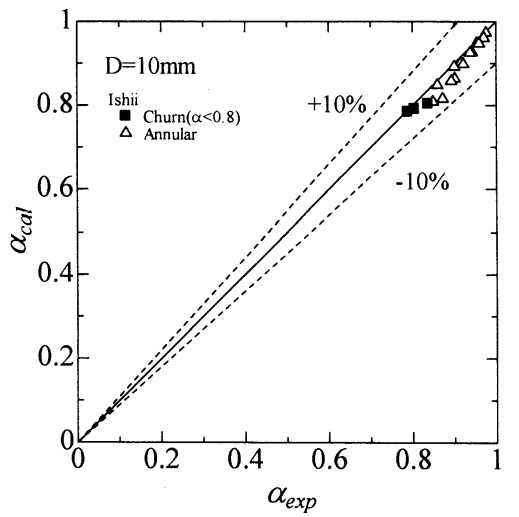

(a) $10 \mathrm{~mm}$

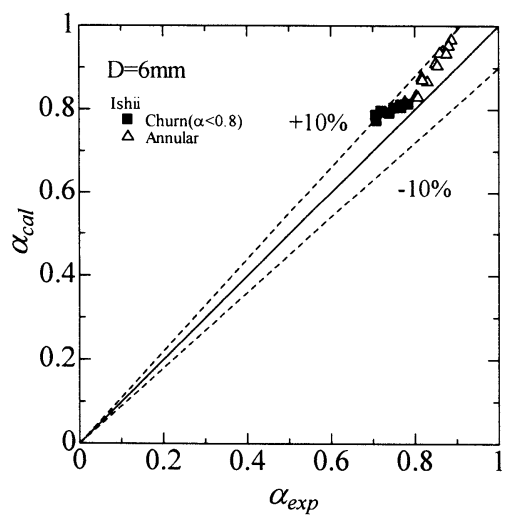

(c) $6 \mathrm{~mm}$

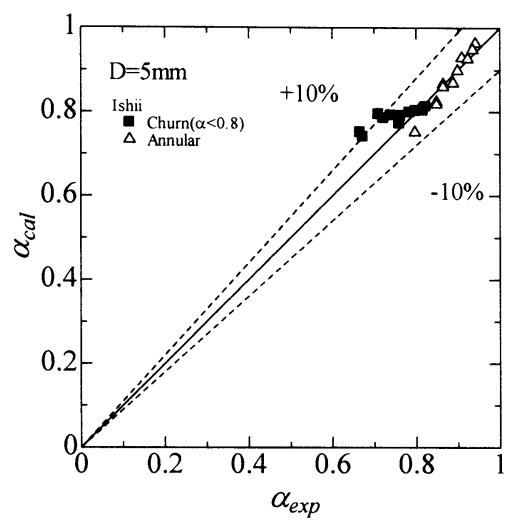

(d) $5 \mathrm{~mm}$

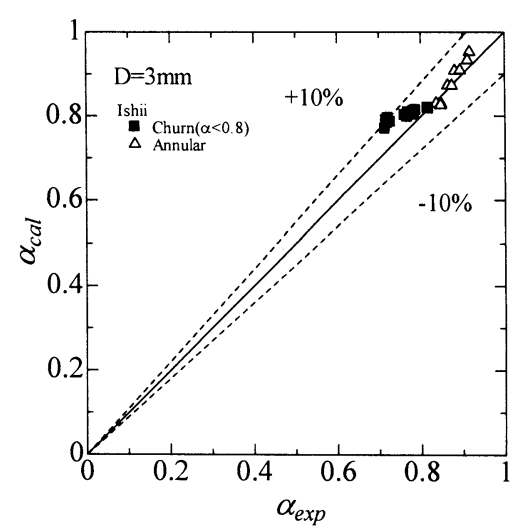

(e) $3 \mathrm{~mm}$

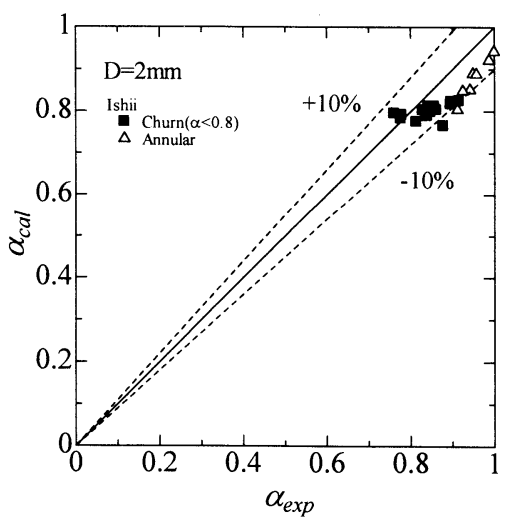

(f) $2 \mathrm{~mm}$

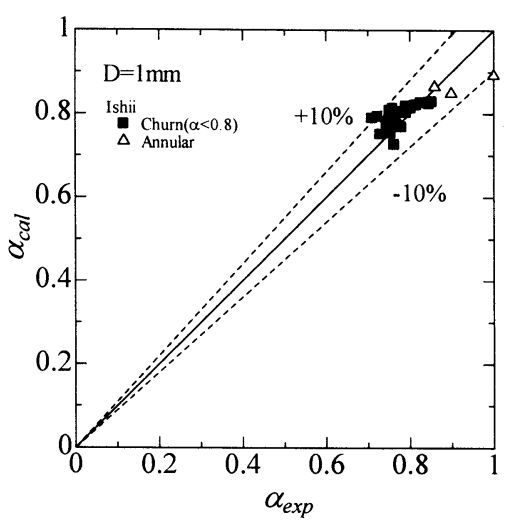

(g) $1 \mathrm{~mm}$

Fig.4 Prediction of the void fraction by Ishii's drift flux model based on the modified flow regime transition 
ともに拡大していることがわかる.この領域は, 管径 の増加とともに縮小し,管内径が約 $60 \mathrm{~mm}$ で消滅する.

図 4 に実験值と修正した流動様式線図に基づく Ishii によるボイド率予測值との比較を示す. Mishima と Ishii の流動様式線図における環状流の $\alpha<0.8$ でのボイ ド率予測值が最大で約 $65 \%$ 修正され，すべての管径に おいて約 $\pm 10 \%$ 以内で予測が行えた. 管径 $1 \mathrm{~mm}$ での 修正領域におけるボイド率予測值に対する実験值の平 均二乗誤差は, 修正前は約 $87 \%$, 修正後は約 4\%であ り，予測精度は大幅に改善されていることが解る.

管径 $10 \mathrm{~mm}$ では, $\alpha=0.8$ を環状流への遷移境界とし 設定したチャーン流の領域をIshii の環状流モデルで予 測しても実験值との差異は小さいことから，10 $\mathrm{mm}$ よ り大きな管径では, ほとんど差がない事が予想され， 従来の研究では，この領域が見落とされていたものと 考えられる.

\section{5. 結}

管内径 1〜10mm の円管について, 中性子ラジオ グラフィにより, 垂直上昇窒素ガスー水気液二相 流のボイド率を計測し, 以下の結論を得た.

(1) 計測したボイド率は, Mishima と Ishii の流動様式線図 の環状流領域で， $\alpha>0.8$ のときは Ishii のモデルと良く一致 したが, $\alpha<0.8$ では一致しなかわた.

(2) Mishima と Hibiki のモデルは, スラグ流 チャーン流 では実験值と一致したが，環状流の $\alpha>0.8$ では一致しなか った.
(3) チャーン流から環状流の遷移が $\alpha=0.8$ で起こると仮定 し, Mishima と Ishii の流重棣式線図にチャーン流から環状 流の遷移線を加えて流動様式を決定すると, $1 \mathrm{~mm}$ から $10 \mathrm{~mm}$ までの全ての管径で Ishii のドリフトフラックスモデ ルによりボイド率が良如予測できることを示した。

\section{文献}

(1) Gibson, A.H., Philos. Mag., 26 (1913), 952-965.

(2) Barnea, D., et al., Can. J. Chem. Eng., 61 (1983), 617.

(3) Mishima, K., and Hibiki, T., Int. J. Multiphase Flow, Vol.22, (1996), 703-712.

(4) Kariyasaki, A., et al., Journal of the Japan Society of Mechanical Engineers, Series B, Vol.58, No. 553 (1992), 2684-2690.

(5) Ide, H., et al., Journal of the Japan Society of Mechanical Engineers, Series B, Vol.63, No.606 (1997), 452-460.

(6) Asano, H., et al., Applied Radiation and Isotopes, 61, (2004), 707-713.

(7) Kureta, N., et al., Journal of the Japan Society of Mechanical Engineers, Series B, Vol.67, No.653 (2001), 179-188.

(8) Kureta, N., et al., Journal of the Japan Society of Mechanical Engineers, Series B, Vol.67, No.661 (2001), 145-153.

(9) Takenaka, N., et al., Nuclear Instruments \& Methods in Physics Research, A 542, (2005), 129-133.

(10) Takenaka, N., et al., Nondestr. Test. Eval., 16(2-6), (2000), 345-354.

(11) Takenaka, N., et al., Key Engineering Materials, (2004), Vols.270-273, 1356-1360.

(12) Ishii, M., ANL-Report, (1977), ANL-77-47.

(13) Mishima, K., and Ishii, M., ANL-Report, (1983), ANL-83-42.

(14) Jones, O.C., and Zuber, N., Int. J. Multiphase Flow, Vol.2, (1975), 273-306. 